\title{
Who is a Global Citizen?
}

\author{
Vincent K Her* \\ Department of Archaeology and Anthropology, University of Wisconsin-La Crosse, USA
}

Submission: February 13, 2018; Published: April 04, 2018

*Corresponding author: Vincent K Her, Department of Archaeology and Anthropology, University of Wisconsin-La Crosse, 1725 State Street, La Crosse, Wisconsin, USA, Tel: 608-785-6632; Email: vher@uwlax.edu

\section{Abstract}

Global citizen is concept with a powerful appeal, but is it achievable? This short commentary is a preliminary attempt to explore both the rhetoric and reality at the heart of this issue. Even though people can traverse the globe with ease, their identities are rooted in their country of citizenship. Tightly controlled, national borders are impermeable to human bodies. Being a global citizen is not yet reality.

Keywords: Globalization; Native; Migration; Anthropocene; Citizenship; Belonging; Identity; national borders; Impermeable; Southeast Asia

\section{Introduction}

Much has changed about the way we think about the interconnectedness of the world. This trend has been driven by globalization, the worldwide intensification of human interactions as a result of migration, international travel and advances in communication technologies, from smart phones to a multitude of social media platforms [1-3]. Globalization is not a thing, but a set of human-driven processes with great ramifications for understanding life in the Anthropocene. One of the consequences of globalization is that it is complicating ideas of citizenship, identity and belonging. Words such as transnationalism, deterritorialization, hybridity, convergence, or Diaspora have been adopted by scholars to signal drastic changes to modern life [3].

For the past seven years, I have taught a course on contemporary global issues where I address a wide range of topics, including how globalization is reshaping cultures and identities everywhere. Classroom discussions have led to new questions: Is global citizenship achievable, or is it just academic rhetoric, rooted in a collective sense of optimism about an imagined future?; what would be the constitutive elements of a global identity?; who can achieve it?; who holds the authority to grant, question, or deny it?; and what roles do existing international borders play in the affirmation of national citizenship and identities? This short commentary is an attempt to look at a core issue underlying these questions. The term 'global citizen' is problematic in that it ignores practical matters of how identity is lived, tracked, surveilled and monitored.

\section{Rootedness of 'Native' Identities Challenged}

Up until the 1980s, the word "native" has had a special meaning in Anthropology. It referred to "persons and groups who belong to those parts of the world that were, and are, distant from the metropolitan West" [4]. Seen through the anthropological gaze, the identity of "natives" was reduced to people who:

a. Were unable to escape the places into which they were born.

b. Were inseparably linked to the land, where they fish, farm and gather resources to maintain their livelihood.

c. Were not modern and could not be modernized.

d. Have not been tainted by the influences of globalization or modernization.

Over the past four decades, all of these assumptions have been challenged; especially by anthropologists who have done research in their own cultures [4-8]. Their contributions have led to a much more fluid understanding of the contemporary identities of all people. Wherever they are, human beings do not live in isolation; their lives are all equally rich and vibrant. Each and every group can adapt and modernize. Even people living in remote places, as Anna Tsing has shown among Meratus Dayaks of Indonesia, are acutely aware of the changes taking place locally and globally [9]. Today, natives walk among us. They are our colleagues, collaborators and contemporaries.

\section{Basis of Fluid Global Identities}

Each of us is a native in the sense that we live some place, and are from somewhere. Our desire to be global has forced us to re-assess our understanding of human identities. These reassessments are informed by the following changes:

a. Compression of time and space: every place on earth is reachable with jumbo-jet travel.

b. Permeability of borders to capital, culture, information and technologies. 
c. deterritorialization and mobility: Millions are on the move as workers, migrants, refugees, or asylees.

d. Non-physical "places" as anchors of group identity: websites and online communities have emerged as productive sites of identity development and formation.

e. Global spread of Homo sapiens: all peoples share a common African ancestor.

These fluid assumptions have given birth to the idea of global citizen. We all belong to the planet called earth; we are all members of the same species [10]. This view is powerful; it suggests that differences in cultures, skin color, or ways of life should no longer matter. To be a global citizen is to belong to the whole world-to every part of it, not just to one place. A global citizen should be able to move freely in and out of different places without constraints. But is this the case?

\section{Global Citizenship is Not Yet Reality}

I have recently returned to Southeast Asia, after 38 years of resettlement in the United States. My family and I were refugees of the Vietnam War. On that trip, I had the opportunity to retrace our footsteps and reflect on the transnational journey that has transformed me into an american. In Southeast Asia, my identity is what it says on my passport. It was not determined by my ethnic, or cultural heritage. Gatekeepers were present at every stop. As a foreigner, my movements were tracked with dates of arrivals and departures. Whether or not I was able to exit through the main gate of an airport was determined by the person behind the counter who is looking at my visa application. She possessed the authority to question my identity and to grant, or deny my entry. In Southeast Asia, I was not seen as a Southeast Asian, or a person of Hmong descent. I was seen as an American.

Even though people can travel anywhere with relative ease, their country of citizenship remains to be an important marker of their identities. We can reach any place on earth within 24 hours, but that does not mean that we can cross national borders freely. National borders remain tightly guarded (with the exception of travel within the European Union). Borders are more permeable to capital, culture and ideas, but less so to human bodies. The rhetoric of global citizenship is appealing, but it will not become a reality, so long as the sovereignty of nation states is intact. My experience in Southeast Asia has led me to think more critically about the way I talk about global citizenship in the classroom. As educators, we should emphasize the reality of how identities are lived and not add to the hype of an ideal.

\section{References}

1. Arjun A (1990) Disjuncture and Difference in the Global Cultural Economy. Theory, Culture \& Society 7: 295-310.

2. Nayan C (2007) Bound Together: How Traders, Preachers, Adventurers, and Warriors Shaped Globalization. Yale University Press, New Haven, CT, USA.

3. Marita S, Lisa C (2009) The Global Flow of Visual Culture. In: Maria S, Lisa C (Eds.), Practices of Looking: An Introduction to Visual Culture. Oxford University Press, Oxford, UK, pp. 389-426.

4. Arjun A (1988) Putting Hierarchy in Its Place. Cultural Anthropology 3(1): $36-49$

5. Kirin N (1993) How Native Is a "Native" Anthropologist? American Anthropologist. New Series 95(3): 671-686.

6. Soraya A, El-Solh FC (1988) Arab Women in the Field: Studying Your Own Society. Syracuse University Press, Syracuse, NY, USA.

7. Hussein F (1982) Carolina Academic Press, Durham, NC, USA.

8. Ohnuki-Tierney E (1984) Native Anthropologists. American Ethnologist 11: 584-586.

9. Tsing AL (1993) In the Realm of the Diamond Queen: Marginality in an Out-of-the-Way Place. Princeton University Press, Princeton, NJ, USA.

10. Michael H (2013) Human Hybrids. Scientific American 308: 66-71.

\section{Your next submission with Juniper Publishers will reach you the below assets}

- Quality Editorial service

- Swift Peer Review

- Reprints availability

- E-prints Service

- Manuscript Podcast for convenient understanding

- Global attainment for your research

- Manuscript accessibility in different formats

( Pdf, E-pub, Full Text, Audio)

- Unceasing customer service

Track the below URL for one-step submission https://juniperpublishers.com/online-submission.php 